\title{
Effect of dietary incorporation of walnut cake (Juglans regia) on calcium - phosphorus balance and blood biochemical parameters in goats
}

\author{
Mohsin A. Mir, R. K. Sharma, Ankur Rastogi*, Zulfqarul Haq, \\ and Imran A. Ganai \\ Division of Animal Nutrition, Sher-e-Kashmir University of Agricultural Sciences and Technology of Jammu, \\ R S Pura, Jammu (J\&K), India
}

MIR, M. A., R. K. SHARMA, A. RASTOGI, Z. HAQAND, I. A. GANAI: Effect of dietary incorporation of walnut cake (Juglans regia) on calcium - phosphorus balance and blood biochemical parameters in goats. Vet. arhiv 88, 763-771, 2018.

\section{ABSTRACT}

Twelve local adult male goats were randomly allotted to two equal groups and were kept on ad libitum wheat straw, supplemented with either conventional concentrate mixture (Control) or concentrate mixture containing walnut cake $(10 \% \mathrm{w} / \mathrm{w})$ (Treatment). Positive balances of calcium and phosphorus were observed in both groups without any significant $(\mathrm{P}>0.05)$ difference. Blood biochemical parameters were within normal reference limits without any significant difference between dietary treatments, except a significant linear increase $(\mathrm{P}<0.05)$ in aspartate aminotransferase activity in the treatment group, as the feeding trial progressed. It may be concluded that incorporation of up to $10 \%$ of walnut cake in the concentrate mixture does not lead to any negative effect on the calcium and phosphorus balance in adult male goats, however, it may cause hepatotoxic effects, as indicated by the elevated aspartate aminotransferase levels and therefore caution needs to be exercised in incorporating walnut cake in ruminant rations.

Key words: AST; goats; hepatotoxicity; mineral balance; walnut

\section{Introduction}

Feed shortage is a major hurdle limiting animal performance and production in developing countries. Shortages are aggravated further by direct competition for food resources shared between livestock and the human population (MALLA et al., 2015). An alternative to this situation has been found in identifying, characterizing and promoting utilization of unconventional feedstuffs (FAROOQ et al., 2015).Unconventional feedstuffs reduce livestock dependency on conventional feedstuffs, thereby sparing

\footnotetext{
*Corresponding author:

Ankur Rastogi, Division of Animal Nutrition, FVSc \& AH, SKUAST-J, R.S. Pura, Jammu, India, E-mail: dr ankur76@ rediffmail.com
} 
M. A. Mir et al.: Effect of dietary incorporation of walnut cake (Juglans regia) on calcium - phosphorus balance and blood biochemical parameters in goats

them for alternate use, while concurrently reducing feed costs (MALLA et al., 2015; CHAUDHARY et al., 2017).

Walnut production has been increasing rapidly worldwide. The major walnut growing countries are China, USA, Iran, Ukraine, Turkey and Mexico. As per HSD (2016), India is eighth in terms of walnut production with a 122 thousand ha area under walnut plantation in India and with an annual production of 241 thousand MT in 2013-2014. Jammu and Kashmir contribute around $87 \%$ of the country's production and $95 \%$ of the total value of production. They produce about 209.05 MT of walnut on an area of 93.64 thousand hectares (HSD, 2016).

Walnut kernels unfit for or surplus to human consumption are used to produce oil used in medicine, cosmetics and the soap industry. The cake produced as a by-product of oil extraction is available as a potential feedstuff for livestock. Upon oil extraction, almost $50 \%$ of the weight of the kernel is yielded as walnut cake. There are a few reports of its utilization in livestock rations (HEUZÉ et al., 2012). MIR et al. (2015) reported that up to $10 \%$ walnut cake incorporation in the iso-nitrogenous concentrate mixture does not cause any negative effects on in vitro dry matter digestibility and gas production. Unlike other oilseed cakes, walnut cake has moderate CP content (15.17\%) and high crude fat content $(12.15 \%)$ as comparable to grain by-products. The high fat content becomes rancid fairly rapidly and it should not be kept for more than 2 months after extraction It should be kept dry to prevent mould (HEUZÉ et al., 2017). Farmers in Jammu are utilizing the walnut deoiled cake available from local oil extraction units as a livestock feedstuff, without any scientific backing. The present study was conducted to evaluate the feasibility of utilizing locally available walnut deoiled cake as a feed supplement for goats.

\section{Materials and methods}

Twelve local, non-descript adult male goats of 10-12 months mean age and mean body weight of $21.43 \pm 2.26 \mathrm{~kg}$, were randomly allotted, as per randomized block design, to two equal groups, designated 'Control' and 'Treatment'. The goats were maintained on ad libitum wheat straw supplemented at $20 \mathrm{~g} / \mathrm{kg} \mathrm{W}^{0.75}$ with conventional concentrate mixture, to meet the nutrient requirements, as per RANJHAN, 1998. In the control group the concentrate mixture was maintained as: maize $30 \%$, mustard oil cake $37 \%$, wheat bran $30 \%$, mineral mixture $2 \%$ and salt $1 \%$, or a concentrate mixture containing $10 \%$ walnut cake (w/w; as per MIR et al., 2015). In the treatment group the feed consisted of: maize $25 \%$, mustard oil cake $36 \%$, wheat bran $26 \%$, walnut cake $10 \%$, mineral mixture $2 \%$ and salt $1 \%$ ). Walnut cake was procured from a local oil extraction unit that uses an expeller for oil extraction. The feeding trial was conducted for 30 days along with a mineral balance trial during the last week of the feeding trial. All the experimental goats were kept under uniform management conditions with the provision of individual housing in well-ventilated, cement floored sheds. 
M. A. Mir et al.: Effect of dietary incorporation of walnut cake (Juglans regia) on calcium - phosphorus balance and blood biochemical parameters in goats

Blood from all the experimental goats was collected periodically early in the morning before feeding and watering by jugular vein puncture. Haemoglobin, total serum protein, serum albumin, serum globulin, A:G ratio, serum urea nitrogen, alanine aminotransferase (ALT), aspartate aminotransferase (AST) and alkaline phosphatase (ALP) were estimated in the collected samples as part of the blood biochemical profile using 'ERBA ${ }^{\circledR}$ Mannheim' diagnostic Kits by 'Transasia Bio-medicals Ltd., Mumbai'. Estimation of Calcium and Phosphorus was done as per the protocol described in AOAC (1995).

Statistical analysis was carried out by subjecting the data to an independent sample $t$-test for mineral balance data. The blood-biochemical profile values were subjected to general linear model multivariate analysis (SNEDECOR and COCHRAN, 1994) and significantly different means $(\mathrm{P}<0.05)$ were ranked as per Duncan's multiple range test (DUNCAN, 1955).

\section{Results and discussion}

The calcium and phosphorus balance data of the experimental animals are detailed in Table 1. Calcium intake $(\mathrm{g} / \mathrm{d})$, excretion $(\mathrm{g} / \mathrm{d})$ in faeces and urine were comparable $(\mathrm{P}>0.05)$ between the two dietary treatments. The calcium balance was positive in both the groups. There was no significant $(\mathrm{P}>0.05)$ difference in calcium balance $(\mathrm{g} / \mathrm{d})$ or retention between the two groups. Similarly, phosphorus intake $(\mathrm{g} / \mathrm{d})$, excretion $(\mathrm{g} / \mathrm{d})$ in urine and faeces, balance $(\mathrm{g} / \mathrm{d})$ and retention were comparable $(\mathrm{P}>0.05)$ between the goats, irrespective of the diet.

Table 1 . The effect of feeding walnut cake on the calcium and phosphorus balance in experimental goats

\begin{tabular}{|l|r|r|r|c|}
\hline \multirow{2}{*}{ Attributes } & \multicolumn{4}{|c|}{ Groups } \\
\cline { 2 - 5 } & \multicolumn{1}{|c|}{ Control } & Treatment & SEM & P value \\
\hline Calcium intake $(\mathrm{g} / \mathrm{d})$ & $3.13 \pm 0.37$ & $3.61 \pm 0.41$ & 0.27 & 0.398 \\
\hline Faecal calcium excretion $(\mathrm{g} / \mathrm{d})$ & $1.35 \pm 0.23$ & $1.72 \pm 0.26$ & 0.17 & 0.309 \\
\hline Urinary calcium excretion $(\mathrm{g} / \mathrm{d})$ & $0.23 \pm 0.07$ & $0.21 \pm 0.07$ & 0.05 & 0.874 \\
\hline Total calcium excretion $(\mathrm{g} / \mathrm{d})$ & $1.59 \pm 0.22$ & $1.93 \pm 0.31$ & 0.19 & 0.384 \\
\hline Calcium balance $(\mathrm{g} / \mathrm{d})$ & $1.54 \pm 0.31$ & $1.68 \pm 0.17$ & 0.17 & 0.713 \\
\hline Calcium Retention $(\%$ of intake) & $47.75 \pm 6.98$ & $47.50 \pm 3.71$ & 3.77 & 0.975 \\
\hline Calcium Retention $(\%$ of absorbed) & $60.13 \pm 7.57$ & $61.78 \pm 3.74$ & 4.03 & 0.850 \\
\hline Phosphorus intake $(\mathrm{g} / \mathrm{d})$ & $1.14 \pm 0.14$ & $1.22 \pm 0.14$ & 0.09 & 0.669 \\
\hline Faecal phosphorus excretion $(\mathrm{g} / \mathrm{d})$ & $0.41 \pm 0.09$ & $0.49 \pm 0.09$ & 0.06 & 0.552 \\
\hline Urinary phosphorus excretion $(\mathrm{g} / \mathrm{d})$ & $0.22 \pm 0.06$ & $0.14 \pm 0.03$ & 0.03 & 0.201 \\
\hline Total phosphorus excretion $(\mathrm{g} / \mathrm{d})$ & $0.62 \pm 0.08$ & $0.63 \pm 0.10$ & 0.06 & 0.948 \\
\hline Phosphorus balance $(\mathrm{g} / \mathrm{d})$ & $0.50 \pm 0.09$ & $0.60 \pm 0.08$ & 0.06 & 0.456 \\
\hline Phosphorus retention $(\%$ of intake) & $43.67 \pm 5.91$ & $49.32 \pm 4.19$ & 3.56 & 0.453 \\
\hline Phosphorus retention $(\%$ of absorbed) & $67.27 \pm 9.19$ & $81.66 \pm 2.60$ & 5.04 & 0.163 \\
\hline
\end{tabular}


M. A. Mir et al.: Effect of dietary incorporation of walnut cake (Juglans regia) on calcium - phosphorus balance and blood biochemical parameters in goats

It has been reported that, unlike other concentrate supplements, walnut cake is rich in calcium and poor in phosphorus, which leads to an imbalance in the Calcium : Phosphorous ratio of about 7:1 (MIR et al., 2015). The positive calcium and phosphorus balance in all experimental animals, irrespective of the dietary regimen, suggests that the inclusion of $10 \%$ walnut cake in the concentrate mixture did not impede the process of calcium and phosphorus utilization or assimilation by adult male goats. Notwithstanding the inclusion of walnut cake, there was little variation in the Calcium : Phosphorus ratio of the two concentrate mixtures (3:1 in control and 3.3:1 in Treatment). This was due to the inclusion of walnut cake in the concentrate mixture as an alternative to wheat bran and maize grain, which are a rich source of phosphorus. No previous studies are available to compare our results of mineral balance data.

Table 2. The effect of feeding walnut cake on levels of blood bio-chemicals in experimental goats

\begin{tabular}{|c|c|c|c|c|c|c|}
\hline \multirow[b]{2}{*}{$\begin{array}{l}\text { Attributes/ } \\
\text { Treatments }\end{array}$} & \multicolumn{4}{|c|}{ Days from onset of trial } & \multirow[b]{2}{*}{$\begin{array}{c}\text { Treatment } \\
\text { mean } \pm \text { SEM }\end{array}$} & \multirow[b]{2}{*}{$\begin{array}{c}\mathrm{P} \\
\text { value }\end{array}$} \\
\hline & $0^{\text {th }}$ Day & $10^{\text {th }}$ Day & $20^{\text {th }}$ Day & $30^{\text {th }}$ Day & & \\
\hline \multicolumn{7}{|c|}{ Haemoglobin (g/dL) } \\
\hline Control & 9.26 & 9.02 & 8.99 & 9.85 & $9.28 \pm 0.33$ & \\
\hline Treatment & 7.30 & 8.46 & 9.19 & 9.04 & $8.50 \pm 0.26$ & \\
\hline $\begin{array}{l}\text { Period mean } \pm \\
\text { SEM }\end{array}$ & $8.28 \pm 0.67$ & $8.74 \pm 0.22$ & $9.09 \pm 0.23$ & $9.45 \pm 0.40$ & $8.89 \pm 0.21$ & 0.228 \\
\hline \multicolumn{5}{|l|}{$P$ value } & 0.063 & 0.318 \\
\hline \multicolumn{7}{|c|}{ Blood Urea Nitrogen (mg/dL) } \\
\hline Control & 25.95 & 27.16 & 26.31 & 24.89 & $\begin{array}{l}26.08 \\
\pm 0.73\end{array}$ & \\
\hline Treatment & 26.15 & 27.50 & 25.62 & 27.37 & $\begin{array}{c}26.66 \pm \\
0.71\end{array}$ & \\
\hline $\begin{array}{l}\text { Period mean } \pm \\
\text { SEM }\end{array}$ & $\begin{array}{l}26.05 \\
\pm 0.79\end{array}$ & $\begin{array}{l}27.33 \\
\pm 1.05\end{array}$ & $\begin{array}{l}25.97 \\
\pm 1.09\end{array}$ & $\begin{array}{l}26.13 \\
\pm 1.16\end{array}$ & $\begin{array}{l}26.37 \\
\pm 0.51\end{array}$ & 0.776 \\
\hline \multicolumn{5}{|l|}{$P$ value } & 0.588 & 0.754 \\
\hline \multicolumn{7}{|c|}{ Total Protein (g/dL) } \\
\hline Control & 5.93 & 5.98 & 6.35 & 6.13 & $6.10 \pm 0.13$ & \\
\hline Treatment & 5.97 & 6.38 & 6.44 & 6.36 & $6.29 \pm 0.12$ & \\
\hline $\begin{array}{l}\text { Period mean } \pm \\
\text { SEM }\end{array}$ & $5.95 \pm 0.16$ & $6.18 \pm 0.22$ & $6.39 \pm 0.11$ & $6.25 \pm 0.19$ & $6.19 \pm 0.09$ & 0.366 \\
\hline \multicolumn{5}{|l|}{ P value } & 0.299 & 0.894 \\
\hline
\end{tabular}


M. A. Mir et al.: Effect of dietary incorporation of walnut cake (Juglans regia) on calcium - phosphorus balance and blood biochemical parameters in goats

Table 2. The effect of feeding walnut cake on levels of blood bio-chemicals in experimental goats (continued)

\begin{tabular}{|c|c|c|c|c|c|c|}
\hline \multirow[b]{2}{*}{$\begin{array}{l}\text { Attributes/ } \\
\text { Treatments }\end{array}$} & \multicolumn{4}{|c|}{ Days from onset of trial } & \multirow[b]{2}{*}{$\begin{array}{c}\text { Treatment } \\
\text { mean } \pm \text { SEM }\end{array}$} & \multirow[b]{2}{*}{$\begin{array}{c}\mathrm{P} \\
\text { value }\end{array}$} \\
\hline & $0^{\text {th }}$ Day & $10^{\text {th }}$ Day & $20^{\text {th }}$ Day & $30^{\text {th }}$ Day & & \\
\hline \multicolumn{7}{|l|}{ Albumin (g/dL) } \\
\hline Control & 3.32 & 3.29 & 3.14 & 3.19 & $3.23 \pm 0.06$ & \\
\hline Treatment & 3.25 & 3.18 & 3.26 & 3.02 & $3.18 \pm 0.09$ & \\
\hline $\begin{array}{l}\text { Period mean } \pm \\
\text { SEM }\end{array}$ & $3.29 \pm 0.13$ & $3.23 \pm 0.10$ & $3.20 \pm 0.10$ & $3.10 \pm 0.10$ & $3.21 \pm 0.05$ & 0.712 \\
\hline$P$ value & & & & & 0.621 & 0.805 \\
\hline \multicolumn{7}{|l|}{ Globulin (g/dL) } \\
\hline Control & 2.61 & 2.69 & 3.21 & 2.94 & $2.86 \pm 0.13$ & \\
\hline Treatment & 2.71 & 3.20 & 3.17 & 3.35 & $3.11 \pm 0.17$ & \\
\hline $\begin{array}{l}\text { Period mean } \pm \\
\text { SEM }\end{array}$ & $2.66 \pm 0.22$ & $2.95 \pm 0.26$ & $3.19 \pm 0.10$ & $3.14 \pm 0.24$ & $2.99 \pm 0.11$ & 0.314 \\
\hline $\mathrm{P}$ value & & & & & 0.270 & 0.797 \\
\hline \multicolumn{7}{|l|}{ A:G Ratio } \\
\hline Control & 1.30 & 1.29 & 0.99 & 1.17 & $\begin{array}{l}1.19 \pm \\
10.06\end{array}$ & \\
\hline Treatment & 1.44 & 1.11 & 1.05 & 0.99 & $1.14 \pm 0.10$ & \\
\hline $\begin{array}{l}\text { Period mean } \pm \\
\text { SEM }\end{array}$ & $1.37 \pm 0.16$ & $1.20 \pm 0.11$ & $1.02 \pm 0.06$ & $1.08 \pm 0.11$ & $1.17 \pm 0.06$ & 0.176 \\
\hline$P$ value & & & & & 0.718 & 0.696 \\
\hline
\end{tabular}

The blood biochemical profile of the experimental animals is presented in Table 2. There were no significant $(\mathrm{P}>0.05)$ differences in haemoglobin concentrations over the collection periods, nor between the two dietary treatments. The mean haemoglobin level of the experimental animals was almost $8.50 \pm 0.26 \mathrm{~g} / \mathrm{dL}$, which is within the normal range (8-12 g/dL) as per KANEKO et al. (2008) for goats. Mean blood urea nitrogen showed no significant $(\mathrm{P}>0.05)$ difference between the groups. Blood urea nitrogen levels are an indicator of the protein nutrition status of the animal (BAKER et al.,1995) and the level observed is similar to that reported by JAN et al. (2015). 
M. A. Mir et al.: Effect of dietary incorporation of walnut cake (Juglans regia) on calcium - phosphorus balance and blood biochemical parameters in goats

Table 3. The effect of feeding walnut cake on levels of serum enzymes in experimental goats

\begin{tabular}{|c|c|c|c|c|c|c|}
\hline \multirow[t]{2}{*}{$\begin{array}{l}\text { Attributes/ } \\
\text { Treatments }\end{array}$} & \multicolumn{4}{|c|}{ Days from onset of trial } & \multirow{2}{*}{$\begin{array}{c}\text { Treatment } \\
\text { Mean } \pm \text { SEM }\end{array}$} & \multirow[b]{2}{*}{ P value } \\
\hline & $0^{\text {th }}$ Day & $10^{\text {th }}$ Day & $20^{\text {th }}$ Day & $30^{\text {th }}$ Day & & \\
\hline \multicolumn{7}{|l|}{ AST (IU/L) } \\
\hline Control & 57.45 & 55.73 & 62.00 & 66.29 & $60.37 \pm 2.12$ & \\
\hline Treatment & 58.71 & 75.63 & 88.43 & 104.41 & $81.79 \pm 4.82$ & \\
\hline $\begin{array}{l}\text { Period mean } \\
\pm \text { SEM }\end{array}$ & $58.08^{\mathrm{a}} \pm 3.75$ & $65.68^{\mathrm{ab}} \pm 4.37$ & $75.22^{\mathrm{bc}} \pm 6.98$ & $85.35^{c} \pm 6.15$ & $71.08 \pm 3.04$ & 0.000 \\
\hline \multicolumn{5}{|l|}{ P value } & 0.000 & 0.024 \\
\hline \multicolumn{7}{|l|}{ ALT (IU/L) } \\
\hline Control & 23.28 & 25.72 & 23.77 & 19.37 & $23.03 \pm 1.30$ & \\
\hline Treatment & 22.86 & 21.73 & 23.95 & 23.59 & $23.03 \pm 1.05$ & \\
\hline $\begin{array}{l}\text { Period mean } \\
\pm \text { SEM }\end{array}$ & $23.07 \pm 1.01$ & $23.73 \pm 2.62$ & $23.86 \pm 1.36$ & $21.48 \pm 1.28$ & $23.03 \pm 0.83$ & 0.747 \\
\hline \multicolumn{5}{|l|}{ P value } & 0.998 & 0.417 \\
\hline \multicolumn{7}{|c|}{ AST : ALT ratio } \\
\hline Control & 2.50 & 2.45 & 2.70 & 3.51 & $2.79 \pm 0.18$ & \\
\hline Treatment & 2.61 & 3.84 & 3.93 & 4.60 & $3.74 \pm 0.28$ & \\
\hline $\begin{array}{l}\text { Period mean } \\
\pm \text { SEM }\end{array}$ & $2.55^{\mathrm{a}} \pm 0.19$ & $3.14^{\mathrm{ab}} \pm 0.41$ & $3.31^{\mathrm{ab}} \pm 0.39$ & $4.05^{b} \pm 0.31$ & $3.27 \pm 0.18$ & 0.014 \\
\hline \multicolumn{5}{|l|}{$\mathrm{P}$ value } & 0.004 & 0.458 \\
\hline \multicolumn{7}{|l|}{$\operatorname{ALP}(\mathrm{IU} / \mathrm{L})$} \\
\hline Control & 288.94 & 282.71 & 268.01 & 271.23 & $277.72 \pm 9.09$ & \\
\hline Treatment & 296.57 & 298.05 & 290.44 & 290.42 & $293.87 \pm 9.48$ & \\
\hline $\begin{array}{l}\text { Period mean } \\
\pm \text { SEM }\end{array}$ & $\begin{array}{c}292.76 \pm \\
12.40\end{array}$ & $\begin{array}{c}290.38 \pm \\
12.15\end{array}$ & $\begin{array}{c}279.22 \pm \\
14.96\end{array}$ & $\begin{array}{c}280.82 \pm \\
14.39\end{array}$ & $285.80 \pm 6.60$ & 0.871 \\
\hline \multicolumn{5}{|l|}{$\mathrm{P}$ value } & 0.253 & 0.984 \\
\hline
\end{tabular}

${ }^{\text {abc }}$ Means bearing different superscripts within a row differ significantly

Mean total serum protein levels in the experimental goats was in the normal reference range of 6.0-7.5 g/dL for goats (KANEKO et al., 2008). Serum concentration of proteins depends upon a variety of factors, including the nature of hepatic disorders, metabolic hepatic processes and other organ disorders. The levels of total protein and serum albumin indicates the biosynthetic capabilities of the liver (THAPA and WALIA, 2007), 
and hepatocellular toxicity is often indicated by a decline in the albumin : globulin ratio (SINGH et al., 2011). The total protein levels obtained across the time periods and across the different groups were comparable $(\mathrm{P}>0.05)$ and indicate that the dietary regimens did not compromise liver function in terms of biosynthesis. Similar observations were recorded with serum albumin and globulin levels. The levels observed were similar to earlier reports (BASHIR et al., 2014, ISHFAQ et al., 2017).

ALT levels did not vary significantly $(\mathrm{P}>0.05)$ between groups, while AST levels were elevated in the treatment group animals $(\mathrm{P}<0.01)$ (Table 3) with a linear increase in the treatment group with a coefficient of determination $\left(R^{2}\right)$ of 0.9974 . These enzymes are the most commonly used biomarkers for hepatic function assay. In contrast to ALT, which is liver specific, AST is a general marker of tissue damage. The ratio of serum AST to ALT can be used to differentiate liver damage from other organ damage (NATHWANI et al., 2005). Significantly $(\mathrm{P}<0.01)$ the higher AST : ALT ratio in the treatment group suggests that increased AST activity was due to hepato-toxicity caused by the walnut cake fed to the experimental animals. Although the exact cause of this increase could not be ascertained within the scope of the present study, it has been reported that the high tannin content of the walnut seed is a potential hepato-toxicant (FETROW and AVILA, 2004). ALP activity is an indicator of liver function, especially congestion or obstruction of the biliary tract and bone health. Comparable $(\mathrm{P}>0.05)$ ALP levels in both groups, irrespective of dietary intervention, indicate there were no negative effects of the experimental diet on biliary and bone health. However, this result cannot be used to rule out liver injury suggested by AST levels.

\section{Conclusion}

Incorporation of up to $10 \%$ walnut cake in the concentrate mixture does not lead to any negative effect over calcium-phosphorus balance in adult male goats. However, the negative effect over animal health indicated by elevated AST levels, needs further scrutiny. Therefore, caution must be exercised in incorporating walnut cake in ruminant rations even if fed in lower level of inclusion.

\section{References}

AOAC (1995): Official Methods of Analysis. Association of Official Analytical Chemists, $16^{\text {th }}$ ed. Washington, DC., USA.

BAKER, L., J. D. FERGUSON, W. CHALUPA (1995): Responses in urea and true protein of milk to different protein feeding schemes for dairy cows. J. Dairy Sci. 78, 2424-2434.

DOI: $10.3168 /$ jds.S0022-0302(95)76871-0

BASHIR, Y., R. K SHARMA, A. RASTOGI, A. K. PATHAK, N. KHAN (2014): Effect of dietary incorporation of olive (Olea europoea) meal on live weight and heamato-biochemical profile of goats. Vet. Pract. 15, 157-159. 
M. A. Mir et al.: Effect of dietary incorporation of walnut cake (Juglans regia) on calcium - phosphorus balance and blood biochemical parameters in goats

CHAUDHARY, S., A. RASTOGI, R. K. SHARMA, P. RAGHUWANSHI, N. KHAN (2017): Formulation of kinnow mandarin (Citrus nobilis Lour x Citrus deliciosa Tenora) waste and paddy straw based complete feed blocks and its utilization by goats. Ind. J. Anim. Res. 51, 105-110.

DUNCAN, B. B. (1955): Multiple range and multiple 'F' test. Biometrics 11, 1-42. DOI: $10.2307 / 3001478$

FAROOQ, J., R. K. SHARMA, A. RASTOGI, K. BARMAN (2015): Effect of replacement of wheat straw with maize cobs with or without physico-chemical treatment on degradation of dry matter, truly digestible organic matter and production of microbial biomass of composite ration in vitro using goat rumen liquor. J. Anim. Res. 5, 501-510.

DOI: $10.5958 / 2277-940 X .2015 .00086 .8$

FETROW, C. W., J. R. AVILA (2004): Professional's Handbook of Complementary and Alternative Medicines, $3^{\text {rd }}$ ed. Lippincott Williams and Wilkins, Philadelphia.

HEUZÉ, V., G. TRAN, P. HASSOUN, F. LEBAS (2012): Walnut (Juglans regia). Feedipedia.org. A programme by INRA, CIRAD, AFZ and FAO. http://www.feedipedia.org/node/38.

HEUZÉ, V., G. TRAN, P. HASSOUN, F. LEBAS (2017): Walnut (Juglans regia). Feedipedia, a programme by INRA, CIRAD, AFZ and FAO. https://www.feedipedia.org/node/38

HSD (2016): Horticultural statistics at a glance 2015. Horticulture Statistics Division, Department of Agriculture, Cooperation and Farmers Welfare, Ministry of Agriculture and Farmers Welfare, Government of India. Oxford University Press, New Delhi, India.

ISHFAQ, A., R. K. SHARMA, A. RASTOGI, B. A. MALLA, S. A. RATHER (2017): Effect of lime treated olive cake on nutrient utilization and performance of male goats. Ind. J. Anim. Res. 51, 286-290.

JAN, O. Q., N. KAMILI, A. ASHRAF, A. IQBAL, R. K. SHARMA, A. RASTOGI (2015): Haematobiochemical parameters of goats fed tannin rich Psidium guajava and Carissa spinarum against Haemonchus contortus infection in India. J. Parasit. Dis. 39, 41-48.

DOI: $10.1007 / \mathrm{s} 12639-013-0278-5$

KANEKO, J. J., J. W. HARVEY, M. L. BRUSS (2008): Clinical Biochemistry of Domestic Animals, VI ed., Academic Press. San Diego, California, USA.

MALLA, B. A., A. RASTOGI, R. K. SHARMA, A. ISHFAQ, J. FAROOQ (2015): Kinnow mandarin (Citrus nobilis Lour. x Citrus deliciosa Tenora) fruit waste silage as potential feed for small ruminants. Vet. World 8, 19-23.

DOI: 10.14202/vetworld.2015.19-23

MIR, M. A., R. K. SHARMA, A. RASTOGI, K. BARMAN (2015): Effect of incorporation of walnut cake (Juglans regia) in concentrate mixture on degradation of dry matter, organic matter and production of microbial biomass in vitro in goat. Vet. World 8, 1172-1176.

DOI: $10.14202 /$ vetworld.2015.1172-1176

NATHWANI, R. A., S. PAIS, T. B. REYNOLDS, N. KAPLOWITZ (2005): Serum alanine aminotransferase in skeletal muscle diseases. Hepatology 41, 380-382.

DOI: $10.1002 /$ hep. 20548 
M. A. Mir et al.: Effect of dietary incorporation of walnut cake (Juglans regia) on calcium - phosphorus balance and blood biochemical parameters in goats

RANJHAN, S. K. (1998). Nutrient Requirements of Livestock and Poultry. Indian Council of Agricultural Research, New Delhi, India.

SINGH, A., T. K. BHAT, O. P. SHARMA (2011): Clinical biochemistry of hepatotoxicity. J. Clinic. Toxicol. S4:001.

DOI: $10.4172 / 2161-0495 . S 4-001$

SNEDECOR, G. W., W. G. COCHRAN (1994). Statistical Methods. $8^{\text {th }}$ ed., East West Press Private Limited, New Delhi.

THAPA, B. R., A. WALIA (2007): Liver function tests and their interpretation. Ind. J. Pediatr. 74, 663-671.

Received: 14 November 2017

Accepted: 27 May 2018

MIR, M. A., R. K. SHARMA, A. RASTOGI, Z. HAQAND, I. A. GANAI: Utjecaj dodatka pogače s orasima (Juglans regia) na ravnotežu kalcija i fosfora te krvne biokemijske pokazatelje u koza. Vet. arhiv 88, 763-771, 2018.

\section{SAŽETAK}

Ukupno 12 odraslih, nasumce odabranih jarčeva podijeljeno je u dvije jednake skupine hranjene ad libitum. Kontrolna skupina hranjena je slamom s dodatkom komercijalne pogače, dok je pokusna skupina hranjena slamom kojoj je dodana mješavina koncentrata i pogača s orasima (10\%). Pozitivna ravnoteža kalcija i fosfora opažena je u objema skupinama, bez statistički značajne razlike ( $P>0,05)$. Krvni biokemijski pokazatelji bili su u fiziološkim granicama bez značajnih razlika između skupina, osim statistički značajnog linearnog povećanja $(\mathrm{P}<0,05)$ aktivnosti aspartat-aminotransferaze (AST) u pokusnoj skupini kako je pokus napredovao. Može se zaključiti da dodavanje $10 \%$ pogače s orasima u mješavinu koncentrata ne utječe negativno na ravnotežu kalcija i fosfora u odraslih jarčeva, no može imati hepatotoksični učinak, na što upućuje povećana razina AST-a. Stoga je potreban oprez pri dodavanju pogače s orasima u obroke za preživače.

Ključne riječi: AST; jarčevi; hepatotoksičnost; ravnoteža minerala; orasi

Vet. arhiv 88 (6), 763-771, 2018 
